\title{
A születés hete másodszor Vácott
}

\section{Week of "nativity" for the second time in the town of Vác}

\author{
Szerzők: Klinger Mária $\bowtie$ \\ Jótevők Háza Alapítvány
}

Beküldve: 2018. 10. 19.

doi: 10.24365/ef.v59i5.369

Kulcsszavak: perinatális egészséggondozás; várandósság; szülés; szoptatás; gyermeknevelés

Keywords: perinatal health care; pregnancy; childbirth; breastfeeding; child rearing

A születés a világ legnagyobb csodája. Nagyon sok információ áramlik a leendő anya felé, hogy a várandósság alatt milyen készítményeket szedjen, hogyan étkezzen, milyen szülésfelkészítő és egyéb programokra járjon, továbbá hogyan gondozza gyermekét a szülés után. Éppen ezért jött létre 2017-ben Vácon az a kezdeményezés, hogy a Születés hete címú, 2003 óta futó országos programsorozathoz csatlakozva, releváns és hiteles információkhoz juthassanak a kismamák és a kisgyermeküket nevelő szülők. A négynapos programsorozat 2018. október 10-én második alkalommal került megrendezésre Vác Város Önkormányzat Szociális Szolgáltatások Háza, illetve az intézmény alapítványa, a Jótevők Háza Alapítvány közös szervezésében a Madách Imre Művelődési Központ Maklári termében. A fókuszban elsődlegesen a várandósággal, a szüléssel, a csecsemőgondozással és a kisgyermekneveléssel kapcsolatos előadások, interaktív beszélgetések és műhelytalálkozók álltak. Több mint 30 program került megrendezésre, amin átlagosan 15-20 anyuka vett részt gyermekével együtt.

A rendezvényt Sellyei Imre, a Szociális Szolgáltatások Háza igazgatóhelyettese, illetve Klinger Mária, a Jótevők Háza Alapítvány kuratóriumi elnöke, a rendezvény helyi főszervezője, továbbá MiskovicsKobza Zsuzsanna a Születés hete országos koordinátora nyitotta meg. Utána nagyon sok anyuka vett részt babájával és kisgyermekével Hertel Szilvia foglalkozásán, amin a 0-3 éves korú babák, kisgyermekek és szüleik játékosan ismerkedhettek meg a magyar néptánc alapmozdulataival.

Az utána következő szakmai előadásokon az érdeklődő anyukák mellett többek között nagy számban jelentek meg a környék területi védőnői és szociálpedagógusai, illetve az Apor Vilmos Katolikus Főiskola Csecsemő- és Kisgyermeknevelő szakának hallgatói, továbbá a Pivár Ignác Általános Iskola és Speciális Szakiskola háztartástanképzés diákjai.

$\mathrm{Az}$ első napon Miskovics-Kobza Zsuzsanna dúla, szülésfelkészítő és párkapcsolati tanácsadó tartott interaktív előadást az apás szülés párkapcsolatra gyakorolt hatásáról, illetve Gurdon Katalin klinikai szakpszichológus szülésfeldolgozó csoportos bemutatóján osztotta meg saját tapasztalatait.

A szülésfeldolgozó csoport célja, hogy segítsen a szülés körüli pozitív és negatív tapasztalatok megértésében. A csoport tagjai a hasonló élmények megosztásával és meghallgatásával támogathatják egymást a saját megélések érzelmi feldolgozásában. Ez segíthet a következő gyermek vállalására való felkészülésben is. A csoport évente kétszer gyűlik össze a váci Átjáró Mentálhigiénés Irodában. A csoportbemutató hívogató volt a novemberi hasonló eseményhez.

A kisgyermekneveléssel kapcsolatos előadások közül kiemelkedett Stefankovics Éva klinikai szakpszichológus interaktív beszélgetése a szeparációs szorongás, testvérféltékenység, dackorszak és a szülői és párkapcsolati szerepek összeegyeztetése témában. Dr. Marton Anita házi gyermekorvos a 
lázcsillapítás mai irányelveiről adott elő. Kuklisné Greff Ildikó területi védőnő az óvodai fejtetúvizsgálatok fontosságát és a tetvesség kezelési lehetőségeit mutatta be. Bencze Éva mentálhigiénikus a gyermeknevelés mindennapi stresszhelyzeteiről és azok kezeléséről, illetve a feszültségoldó technikákról beszélt. Katona Péter gyógypedagógus az alapozó terápia szerepét mutatta be az iskolai beválással kapcsolatban.

Erdélyiné Kedves Ágota szülő-csecsemő/kisgyermek konzulens az alvásról, altatásról és az együttalvással kapcsolatos félelmekről beszélt. Jindáné dr. Labádi Gabriella babajelbeszéd-oktató bemutatta a babajelbeszéd módszerét, amely segíti a gyermekek nyelvi, kognitiv és érzelmi fejlődését, illetve erősíti a szülő-gyermek köteléket. Bojtos Tünde pszichológus előadásában arról beszélt, hogy milyen a jó mese, illetve hogyan és milyen formában meséljünk gyermekeinknek.

A városban múködő ökoóvodát vezetője, Nemes Sarolta mutatta be. Az óvoda nevelési programja nagy hangsúlyt helyez a gyermekek környezettudatos nevelésére.

A szakmai programok során Kanizsai Nagy Ildikó pszichológus az autizmus korai felismeréséről beszélt. Schulcz Noémi gyógypedagógus a szülő, az óvodapedagógus és a gyógypedagógus szerepét mutatta be az eredményes iskolakezdésben. Welker Judit logopédus az óvodai beszédfejlődésről tartott előadást. Haraszti Hedvig gyógytornász a csecsemőkori mozgásfejlődés ortopédiai vonatkozásaira és azok kezelésére hívta fel előadásában a figyelmet, kiemelten a hanyag tartásra, a gerincferdülésre és a lúdtalpra.

Az alternatív kezelési módszerek közül Polgár Ágnes haladó Bowen-alkalmazó a Bowen-terápia babákkal és mamákkal kapcsolatos eredményeit mutatta be. A Bowen-kezelés lényege, hogy a test különböző részein elvégzett speciális mozdulatokkal újrahangolja az agyban a kikapcsolt vagy rosszul múködő idegpályákat, feszültségmentesít és enyhülést ad. A szabadidős babás programok közül Faludi Szilvia zenebölcsije, a Váci Bodza Múhely énekes foglalkozásai és baba-mama tornája, Stefankovics Éva hordozókendő-bemutatója, a Helen Doron-féle játékos angol foglalkozás, illetve Kuruczné Csizek Ildikó jógaoktató szülés utáni regeneráló és babamama jógája vonzotta leginkább az anyukákat.

A szombati nap a várandósoké volt. A szakmai előadásokat Kuklisné Greff Ildikó területi védőnő kezdte, aki a várandósság alatti védőnői vizsgálatok közül kiemelte a terhességi toxémia szúrését, ami még sajnos napjainkban is növelheti az anyai halandóságot. Dr. Székely Zsófia pszichológus doktori disszertációjának eredményeit mutatta be, amiben a segítő kapcsolat fontosságát járta körül a vajúdás és a szülés során. A kismamák relaxálását Kuruczné Csizek Ildikó mentálhigiénés szakember, dúla és jógaoktató várandós jógája segítette.

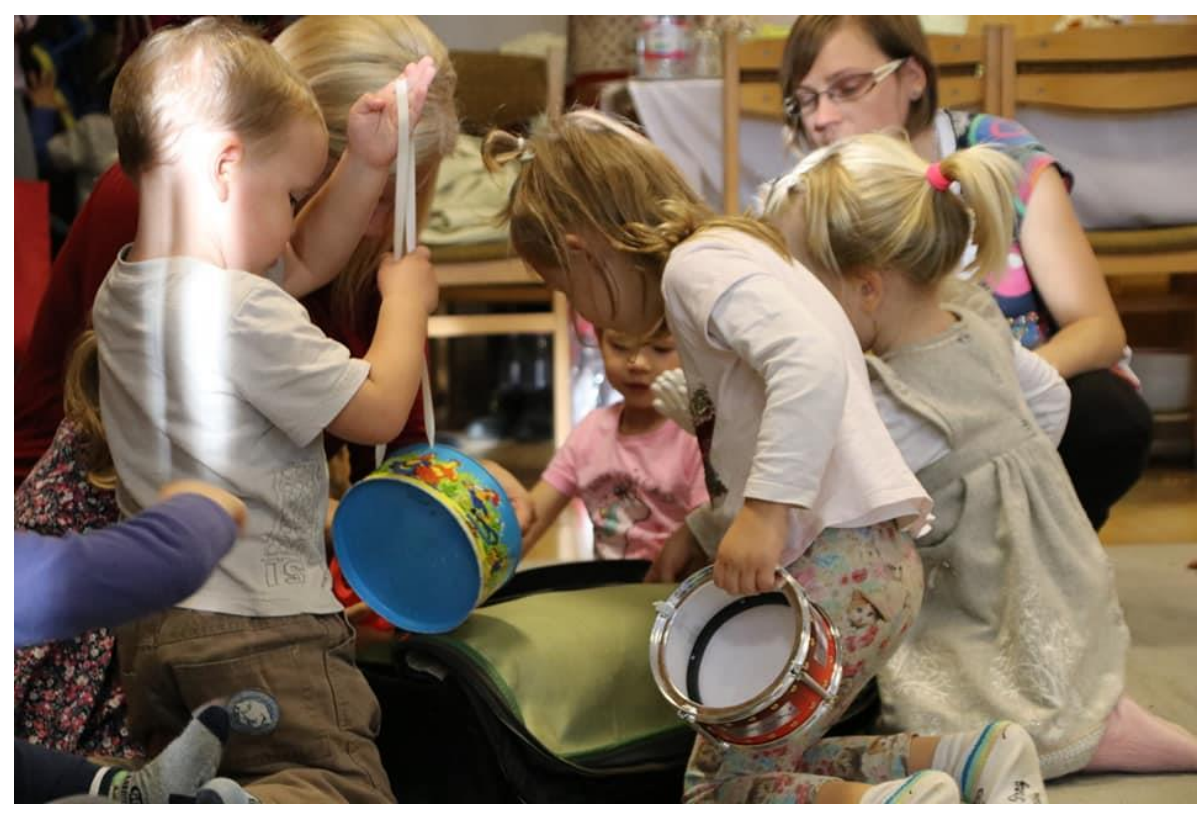


Dr. Pilling Martina szoptatási tanácsadó először bemutatta, hogy mivel tud segíteni az kismamáknak a várandósság során a szoptatásra való felkészüléssel, az otthoni családi tanácsadással szoptatási nehézségek esetén, illetve szoptatást támogató csoportok vezetésével. Az előadásában igyekezte megmutatni, hogy a szoptatás nem csak egy táplálkozási forma, hanem sokkal több: altatásra, fájdalomcsillapításra és vigasztalásra is használhatják az édesanyák. A sikeres szoptatáshoz nagyon fontos a jó kezdet, az aranyóra, a bőrkontaktus, de nem csak a szülőszobában, hanem később az újszülött osztályon, illetve otthon is. Az előadás része volt egy filmvetítés is: Dr. Jack Newman, világhírű szoptatási szakember oktató filmje, amiben lehetőség volt megismerni a három leggyakoribb szoptatási nehézséget és az ilyenkor legjobban múködő megoldásokat: nem megfelelő tejtermelődést, fájdalmas mellbimbót és a mellet elutasító babát.

A szülésre való felkészüléssel kapcsolatban három szakember különböző szemléletéből kaphattunk ízelítőt. Polacsek Gabriella, a váci Jávorszky Ödön Kórház szülésznője a kórház adta új lehetőségekről beszélt a szülés és a gyermekágy kapcsán. A szülésznő fontosnak tartja, hogy biztonságos kórházi körülmények között is meg lehet teremteni a háborítatlan szüléshez szükséges körülményeket. Az alternatív fájdalomcsillapítás lehetőségeiről Kiss-Németh Anita dúla és szülésfelkészítő beszélt. A szülésfelkészítő lehetőséget ad az anyáknak, hogy felfedezhessék a szülés természetes és örömteli oldalát. Nagyon fontos, hogy a nők megértsék, mi történik egy normális, élettani szülésnél, ehhez pedig megnyugtató, világos információk kellenek, amelyek segítenek eloszlatni a félelmek nagy részét. Dömötös Rita, „KG” hipnoszülésre felkészítő szakértő a hipnoszülést mutatta be, amely által olyan relaxációs, vizualizációs technikákat tanulhat meg a szülő nő, amelyek csökkentik félelmeit, és enyhítik a züléssel járó kellemetlen élményeket. Ugyanakkor a módszernek csak az egyik része, hogy a nő elsajátítja az önhipnózis módszerét, a mély relaxálást, illetve a különféle légzőtechnikákat, a másik fontos része a kísérő vagy a társ bevonása, ezért ennek a személynek a szülés előtti teljes felkészülése is szerepel a programban.

A rendezvényt színesítette, hogy biogazdálkodásból származó sárgarépa, alma és sütőtök várta az éhes babákat és anyukákat. Minden nap délután értékes nyereményeket lehetett nyerni a tombolahúzás során. A kiállítóknál pedig a városi gyermekes foglalkozásokkal, illetve mentálhigiénés szolgáltatásokkal, alternatív csecsemőgondozási lehetőségekkel, mosható pelenkákkal, étrend-kiegészítő termékekkel ismerkedhettek meg az érdeklődők, illetve lehetőség volt horgolt és használt játékok megvásárlására is. Továbbá Galisz Virág fotóművész szülésről készült fotókiállítását is megtekinthettük. A szerdától szombatig tartó programsorozat legszebb pillanatairól remek fotók készültek, melyeket a Váci baba-mama és várandós klub Facebook-oldalán lehet megtekinteni.

A programsorozat nem titkolt célja volt az is, hogy olyan közösségi teret hívjon életre, ahol a leendő anyukák a kisgyermekes anyukákkal ismerkedhetnek, és nyíltan oszthatják meg egymással érzelmeiket és tapasztalataikat. Öröm volt látni, hogy milyen barátságok és támogató kapcsolatok születtek.

Ezúton szeretnénk megköszönni a részvételt minden kedves érdeklődőnek, kismamának, babának, várandósnak, szakembernek és kiállítónak, hogy megjelenésükkel megtisztelték programjainkat. Találkozzunk jövőre is!

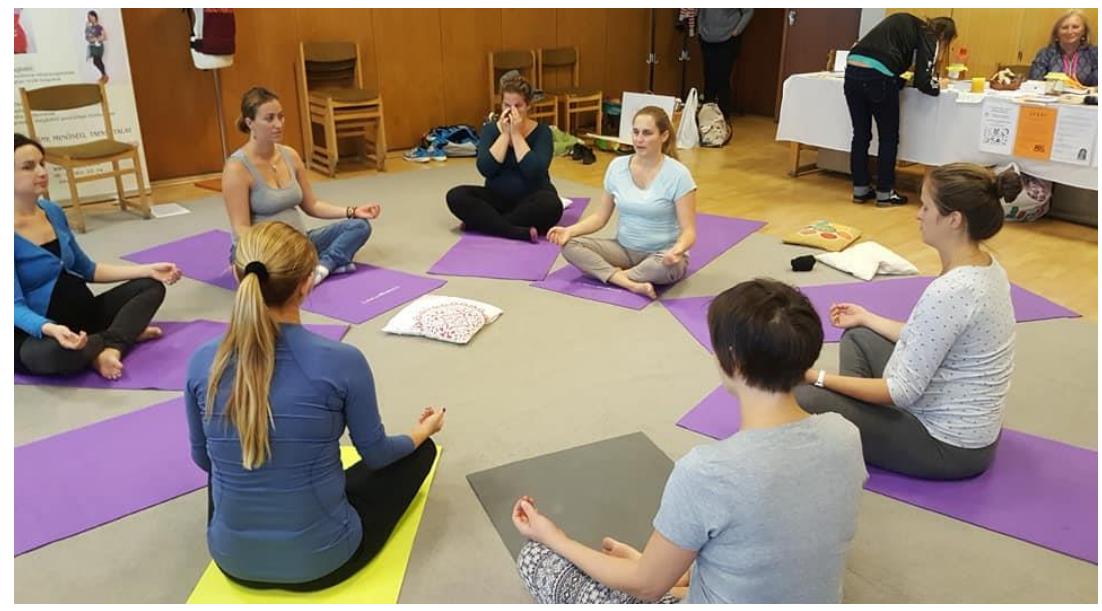

